\title{
ANTIOXIDANT CAPACITY AND ANTIMICROBIAL EFFECTS OF ZINC COMPLEXES OF FLAVONOIDS - DOES SYNERGISM EXIST?
}

\author{
Leposava Pavun ${ }^{1}$, Aleksandra Janošević-Ležaić ${ }^{1}$, Slađana Tanasković ${ }^{2}$, Dušan Ušjak ${ }^{2}$, \\ Marina Milenković², Snežana Uskoković-Marković ${ }^{4 *}$ \\ ${ }^{1}$ Faculty of Pharmacy, University of Belgrade, Department of Physical Chemistry and Instrumental \\ Methods, Vojvode Stepe 450, 11000 Belgrade, Serbia \\ ${ }^{2}$ Faculty of Pharmacy, University of Belgrade, Department of General and Inorganic Chemistry, \\ Vojvode Stepe 450, 11000 Belgrade, Serbia \\ ${ }^{3}$ Faculty of Pharmacy, University of Belgrade, Department of Microbiology and Immunology, \\ Vojvode Stepe 450, 11000 Belgrade, Serbia \\ ${ }^{4}$ Faculty of Pharmacy, University of Belgrade, Department of Analytical Chemistry, \\ Vojvode Stepe 450, 11000 Belgrade, Serbia \\ snezaum@pharmacy.bg.ac.rs
}

There is a constant need for effective drugs, combinations of drugs and methods for the prevention of bacterial and viral infections, including coronavirus. It is known that the role of trace elements in strengthening the human immune system is significant. Vitamins, trace elements, including zinc, iron, selenium, magnesium and copper, and omega-3 fatty acids, play essential physiological roles in promoting the immune system. Zinc is a necessary microelement for basic enzymatic physiological processes; it plays an important role in cell division and is involved in the development of cells responsible for nonspecific immunity. Zinc deficiency is known to predispose patients to viral infection due to reduced antiviral immunity. In addition, flavonoids as plant metabolites play an important role in oxidative stress prevention. This manuscript aims to discuss the roles of zinc, flavonoids and their complexes in vitro, as well as their antioxidant and antimicrobial activities. The justification for the simultaneous use of zinc and flavonoids is also considered.

Keywords: flavonoids; zinc; antioxidants; antimicrobial effect

\section{АНТИОКСИДАТИВЕН КАПАЦИТЕТ И АНТИМИКРОБНИ ЕФЕКТИ НА КОМПЛЕКСИ НА ЦИНК СО ФЛАВОНОИДИ - ДАЛИ ПОСТОИ СИНЕРГИЗАМ?}

Постои постојана потреба од ефикасни лекови, комбинации на лекови и методи за спречување на бактериски и вирусни инфекции, вклучувајќи го и коронавирусот. Познато е дека улогата на елементи во траги во зајакнување на човековиот имун систем е значајна. Витамините, микроелементите, вклучувајќ́ цинк, железо, селен, магнезиум и бакар, масните киселини омега-3 играат значајна физиолошка улога во унапредување на имуниот систем. Цинкот е неопходен микроелемент за основните ензимски физиолошки процеси. Тој игра важна улога во делбата на клетките и е вклучен во развојот на клетки одговорни за неспецифичен имунитет. Познато е дека недостигот на цинк ги предиспонира пациентите на вирусни инфекции поради намалениот антивирусен имунитет. Од друга страна, флавоноидите како метаболити на растенијата играат важна улога во спречување на оксидативен стрес. Овој труд има за цел да ја дискутира in vitro улогата на цинкот, флавонидите и нивните комплекси, како и нивните антиоксидативни и антимикорбни активности. Разгледана е и оправданоста за истовремена употреба на цинк и флавоноиди.

Клучни зборови: флавоноиди; цинк; антиоксиданси; антимикробно дејство 


\section{INTRODUCTION}

Flavonoids are considered to be an abundant class of secondary metabolites of plants, possessing a polyphenolic structure (Fig. 1), providing pollination and color [1, 2], and improving the self-protective ability of the plants, such as serving as UV filters, detoxifying agents, or antimicrobial compounds [3].

According to their structures, flavonoids are divided into several subclasses, namely flavones, flavonols, isoflavonoids, flavanones, anthocyanins, and chalcones [4]. The classification is based on which carbon of the C-ring is the B-ring attached (Fig. 1) and the degree of unsaturation and oxida- tion of the C-ring. Positive pharmacological effects of flavonoids have been well known for decades. Flavonoids have the potential for use as drugs in the prevention of oxidative stress by removing reactive oxygen species [5-9]. The most frequent benefit of flavonoid intake is reflected in the cardiovascular status of tested individuals $[9,10]$; and can also prevent the apoptotic signaling cascade, which stimulates cell death, by performing a wide range of anticancer effects: they modulate ROS-scavenging enzyme activities, participate in arresting the cell cycle, induce apoptosis and autophagy, and suppress cancer cell proliferation and invasiveness [11].

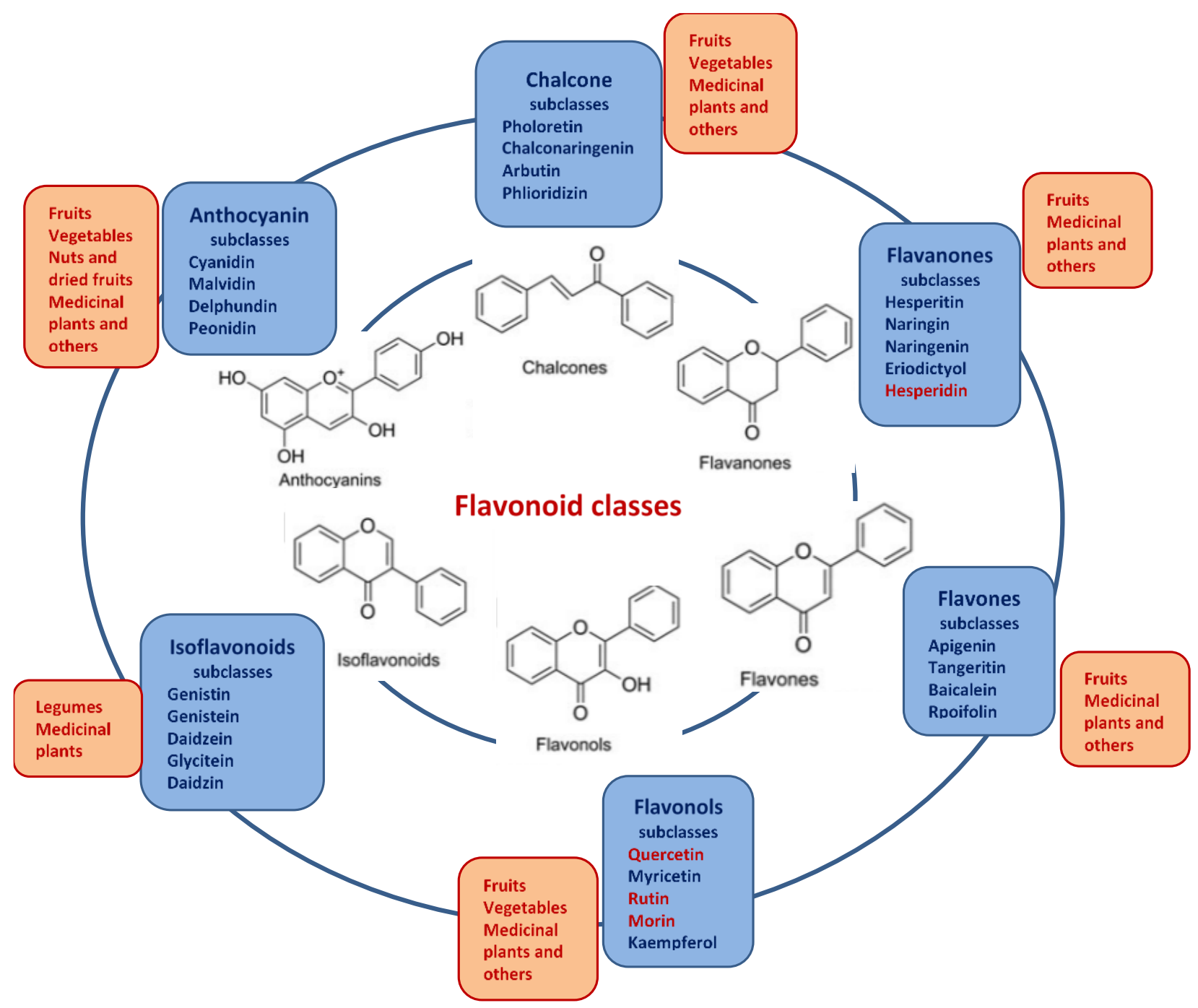

Fig 1. Flavonoid structures and their natural sources

It has been shown that quercetin increases the cytoplasmic membrane permeability of the Gram-positive pathogens Staphylococcus aureus, $S$. haemolyticus, and S. pyogenes, and also protects against the Gram-negative Escherichia coli and
Klebsiella pneumoniae [12]. Flavonoids have been found to inhibit viruses through various mechanisms. Quercetin was found to exhibit its antiviral activity against vesicular stomatitis virus (VSV) and inhibit influenza A virus in vitro by 
virus entry inhibition, and also to block viral binding and entry of herpes simplex virus (HSV)-1, HSV-2, and drug-resistant HSV-1. Rutin was shown to block the entry of human immunodeficiency virus (HIV)-1 without interactions with the host cell membrane [13]. Flavonoids have antiallergic activities [14] and positive effects on brain health [15]. In spite of the numerous positive effects of daily flavonoid intake [16], the consumption of this type of nutraceutical, or of the supplements originating from them, have to be reasonable [17].

Total flavonoid content (TFC) is one of the most important quality parameters for natural sources of flavonoids. HPLC is the method of choice for the separation of complex mixtures containing nonvolatile compounds such as flavonoids in plant material extracts [18-20]. Another often-applied method is GC, which is able to follow the concentration of certain components after fruit consumption, even in plasma [21]. A method with very low LOD and LOQ values is spectrofluorometry; thus, it is applicable for monitoring the level of flavonoids in bio-fluids [22, 23]. As stated previously, the particular bioactivities of flavonoids, such as anticancer and anti-inflammatory properties, are strictly linked to their antioxidant activities. For this reason, electroanalysis helps to understand better the conditioning between the structure of flavonoids and their antioxidant capacities [24]. In recent years, as a very useful tool, electrochemical sensors based on carbon nanomaterials for detecting flavonoids in food have been the subject of detailed studies [25]. Near-infrared (NIR) spectroscopy is another convenient method for quantitative analysis of TFC and total antioxidant activity in the quality control of plant material [26].

Zinc is a trace element but remains a vital micronutrient for maintaining cellular physiology, such as in cell reproduction, growth, and immunity. Almost all cells in our body contain zinc. The body tightly regulates zinc levels, and stress and infections cause plasma zinc levels to fall. Zinc has a key role as a catalyst in a wide range of reactions and is a catalyst for numerous enzymes. It is important in the structure of cell transport proteins such as vitamins A and D. It is known that over 300 regulatory enzymes require zinc for their inhibition-activation processes. Zinc regulates gene expression. It stabilizes cell membranes, helping to strengthen their defense against oxidative stress. Although zinc is an inactive redox metal, it possesses indirect antioxidant properties through its ability to interact with sulfur. Zinc-sulfur bonding is reversible and controls enzyme catalysis mechanisms within the cell; thereby, intercellular zinc binds strongly with redox-active enzymes and converts others to redox-inert forms [27]. It has been also reported that the changes in zinc homeostasis are substantial and correlate with the severity of sepsis, suggesting that zinc might also be useful as a diagnostic marker for evaluating the severity and predicting the outcome of sepsis [28]. It participates in the synthesis, storage and release of insulin, interacts with platelets in blood clotting, and influences thyroid hormone function. It is necessary for visual pigments, normal taste perception, sperm production, fetal development, and behavior and learning performance [29]. Loss of zinc from biological membranes increases their susceptibility to oxidative damage and impairs their functions. It participates in maintaining the structure of the biomembrane, in DNA and RNA synthesis, and in essential fatty acid metabolism [30]. Zinc also plays a role in cell signaling. It is important in wound healing, as it is required for the functioning of the immune system and in the structure and function of the skin. As an antiviral agent and astringent, it is released into the saliva, relieving cough, nasal drainage, and congestion. It is found in the vesicles of the mossy fiber system of the hippocampus.

Keeping in mind the beneficial effects on human health of flavonoids and zinc themselves, will their complexes lead to more efficient systems? The goal of this study was to evaluate the potential of their combination for enhanced antioxidant and antimicrobial activities and to provide a critical overview of the potential bioeffects of zinc complexes with frequently studied flavonoids (rutin, morin, hesperidin and quercetin); does in vitro synergism exist?

\section{EXPERIMENTAL SECTION}

\subsection{Materials}

Quercetin, morin, rutin, hesperidin, and $\mathrm{KCl}$ (Fluka AG), ABTS (2,2'-azino-bis(3-ethylbenzothiazoline-6-sulfonic acid)), trolox, DPPH (2,2diphenyl-2-picrylhydrazyl), and TPTZ (2,4,6-tris (2piridyl)-s-triazine) (Sigma-Aldrich), and $\mathrm{CH}_{3} \mathrm{OH}$, $\mathrm{CH}_{3} \mathrm{COOH}, \mathrm{CH}_{3} \mathrm{COONa}, \mathrm{ZnCl}_{2}$, (Merck), and $\mathrm{FeSO}_{4} \cdot 7 \mathrm{H}_{2} \mathrm{O}, \mathrm{FeCl}_{3} \cdot 6 \mathrm{H}_{2} \mathrm{O}$ (Zorka-Šabac), all p.a. purity grade, were used without further purification.

The stock solution of zinc chloride $\left(10^{3} \mathrm{~mol} \mathrm{l}^{-1}\right)$ was prepared by dissolving $\mathrm{ZnCl}_{2}$ in doubly distilled water. The stock solution $\left(10^{-4} \mathrm{~mol} \mathrm{l}^{-1}\right)$ of flavonoids (quercetin, morin, rutin, and hesperidin) were prepared by dissolving an appropriate amount 
of flavonoid in methanol $(70 \% \mathrm{v} / \mathrm{v})$, with sonication in an ultrasound bath for $15 \mathrm{~min}$, and stored in a refrigerator.

\subsection{Methods}

Experimental procedures, including sample preparations and conditions for testing the antioxidative ability of the flavonoids and their zinc complexes, were based on the proscriptions for the DPPH and ferric reducing antioxidant power (FRAP) tests previously reported for quercetin and morin [32, 33]. Solutions of flavonoids at a concentration of $5 \cdot 10^{-6} \mathrm{~mol} 1^{-1}$ were used for DPPH assay and to test for antioxidant capacity through the FRAP test. The samples were also checked for their ability to scavenge ABTS free radical $\left(\mathrm{ABTS}^{\bullet+}\right)$ as a fast-screening procedure. The stock solution of $\mathrm{ABTS}^{\bullet+}$ was prepared as described by Hsu et al. [34]. For determination of antioxidant activity, the test sample (in the same concentration as for the DPPH and FRAP tests) was dissolved in $5 \mathrm{ml}$ of $\mathrm{ABTS}^{\circ+}$ solution, mixed thoroughly, and then diluted to $10 \mathrm{ml}$ with PBS buffer, mixed thoroughly and incubated in the dark at room temperature. After 3, 6 and $20 \mathrm{~min}$ the absorbance was recorded at $734 \mathrm{~nm}$ using the Beckman DU 650 spectrophotometer with $1-\mathrm{cm}$ quartz cuvettes and PBS buffer as blank. Results were expressed as \% INH (percentage of $\mathrm{ABTS}^{\bullet+}$ inhibition) according to the equation:

$$
\% I N H=\frac{\left[A_{\mathrm{ABTS}^{\bullet+}}-A_{\text {sample }}\right]}{A_{\mathrm{ABTS}+}} \times 100,
$$

where $A_{\mathrm{ABTS}}{ }^{\circ+}$ is the absorbance of $\mathrm{ABTS}^{\bullet+}$ solution $+5 \mathrm{ml}$ of PBS buffer, and $A_{\text {sample }}$ is the absorbance of solution in the presence of sample after 3, 6, or $20 \mathrm{~min}$ of reaction.

Further, the antimicrobial activities of rutin, hesperidin, and morin and their zinc complexes were determined as minimal inhibitory concentration (MIC), according to the procedures already reported for quercetin [32].

\section{RESULTS AND DISCUSSION}

One of the very important characteristics of flavonoids is their ability to form complexes with transition metal ions, especially with zinc [35]. Actually, some of the bio-effectiveness of flavonoids is based on their metal-complex formation. On the other hand, thanks to this characteristic, it was possible to develop the low-cost and efficient spectrophotometric determinations of flavonoids $[32,33,36,37]$. The most important analytical parameters of the reported methods for the determination of certain flavonoids based on zinc complexes are given in Table 1.

T a ble 1

Literature data on the spectrophotometric determination of the selected flavonoids based on their zinc complexes

\begin{tabular}{|c|c|c|c|c|c|c|c|}
\hline Flavonoid & $\begin{array}{l}\text { Stability } \\
\text { constant }\end{array}$ & $\begin{array}{l}\lambda, \\
(\mathrm{nm})\end{array}$ & $\overline{\mathrm{pH}}$ & $\begin{array}{l}\operatorname{LOD}\left(\mu \mathrm{g} \mathrm{ml} \mathrm{ml}^{-1}\right) \\
\operatorname{LOQ}\left(\mu \mathrm{gl}^{-1}\right)\end{array}$ & $\begin{array}{l}\text { Linearity } \\
\text { range }\left(\mu \mathrm{g} \mathrm{ml}^{-1}\right)\end{array}$ & $\begin{array}{l}\text { Applicable on } \\
\text { samples }\end{array}$ & Ref \\
\hline Rutin & $\log \mathrm{K}=10.86$ & 410 & 8.52 & $\begin{array}{l}0.21 \\
0.63\end{array}$ & $0.3-12.2$ & $\begin{array}{l}\text { Herbal dietary } \\
\text { supplements }\end{array}$ & [35] \\
\hline Hesperidin & $\log \beta_{2}=17.01$ & 283 & 3.12 & $\begin{array}{l}0.15 \\
0.45\end{array}$ & $0.61-7.32$ & $\begin{array}{l}\text { Supplements (tablets); } \\
\text { orange juices }\end{array}$ & [36] \\
\hline Quercetin & $\log \beta_{2}=10.24$ & 363 & 5.25 & $\begin{array}{l}30 \\
100\end{array}$ & $100-6000$ & $\begin{array}{l}\text { Dietary supplements } \\
\text { (tablets, capsules); } \\
\text { onions }\end{array}$ & [32] \\
\hline Morin & $\log \beta_{1}=7.91$ & 392 & 7.98 & $\begin{array}{l}30 \\
91\end{array}$ & $151-4533$ & Strawberries & [33] \\
\hline
\end{tabular}

First of all, it is interesting to compare and comment on the characteristics of rutin, hesperidin, quercetin, and morin as abundant flavonoids present in commonly consumed fruits and/or vegetables (such as apples, oranges, onions, red fruits, etc.), both fresh and sometimes as juices. Also, they are frequently found ingredients of multicomponent supplements, especially in formulations labeled on the market as "immunocomplexes". Nowadays, when many people around the world are taking zinc supplements on a daily basis, it makes sense to consider zinc-flavonoid combinations.

The selectivity of the reported spectrophotometric methods based on zinc complex formation 
is achieved by careful selection of $\mathrm{pH}$ and the wavelength at which the determination of the flavonoid is performed (Table 1 and Fig. 2). Although morin and quercetin possess very similar structures, as reflected in the similar $\lambda_{\max }$ of the complexes $(\Delta \lambda \sim 30 \mathrm{~nm})$, the persistence of the second $\mathrm{pH}$ maximum for the $\mathrm{Zn}$-morin complex allows the development of selective methods with low LOD and LOQ values.

Besides the successful determination of flavonoids, it was interesting to test and compare the antioxidant capacities of flavonoids alone and of their zinc complexes (Fig. 3).

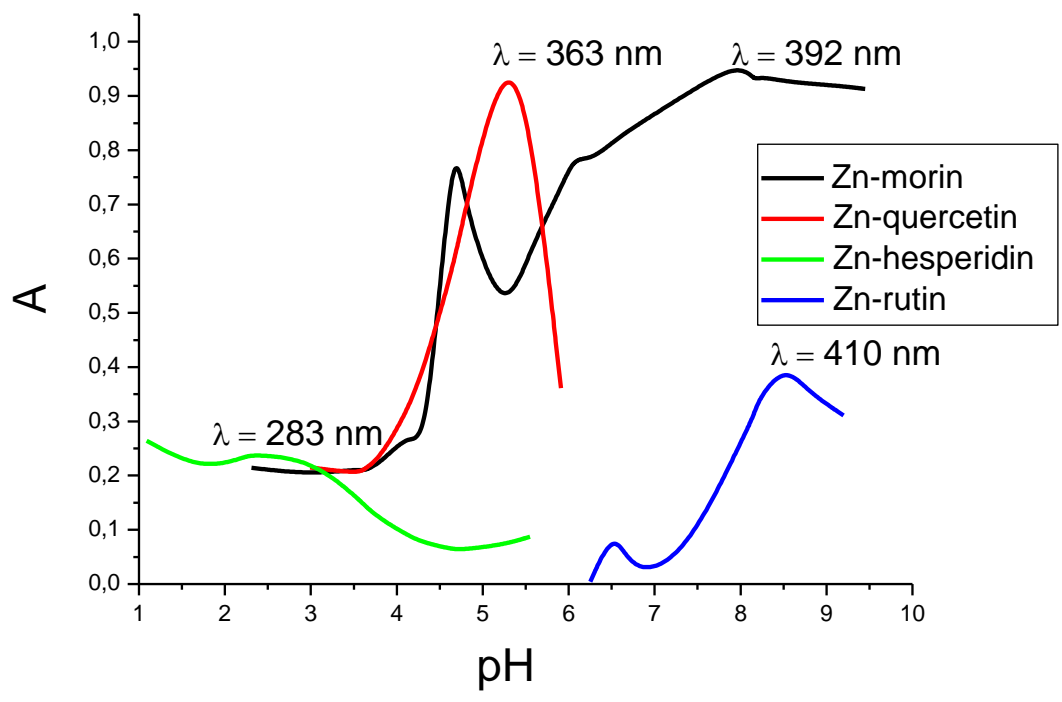

Fig 2. $\mathrm{pH}$ dependence of absorbance of zinc-flavonoid complexes

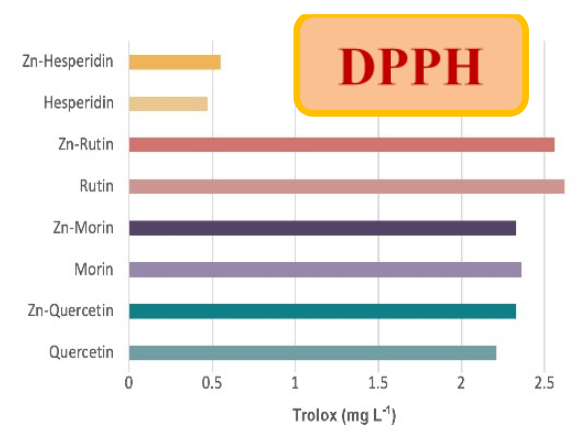

DPPH·

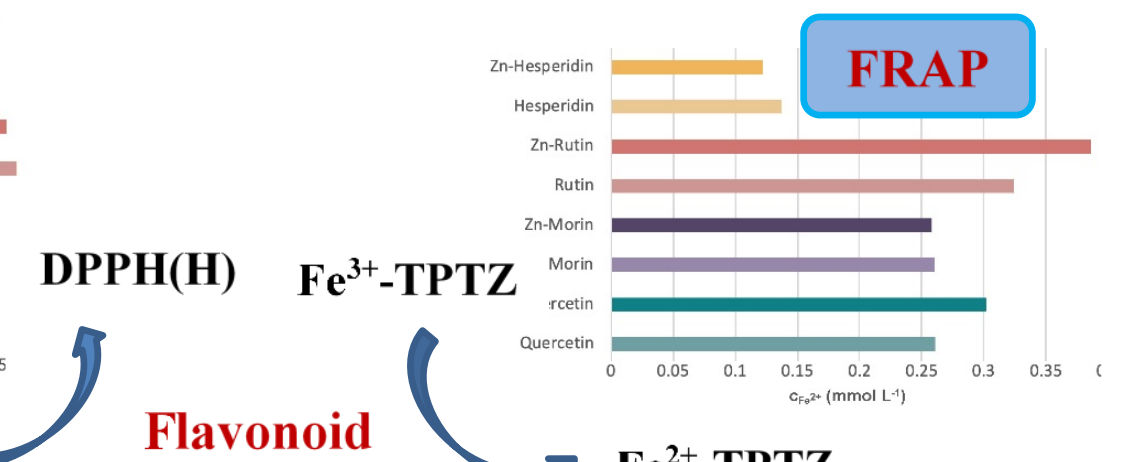

versus

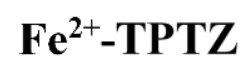 \\ $\mathrm{Fe}^{2+}-\mathrm{TPTZ}$}

\section{Zn-Flavonoid?}
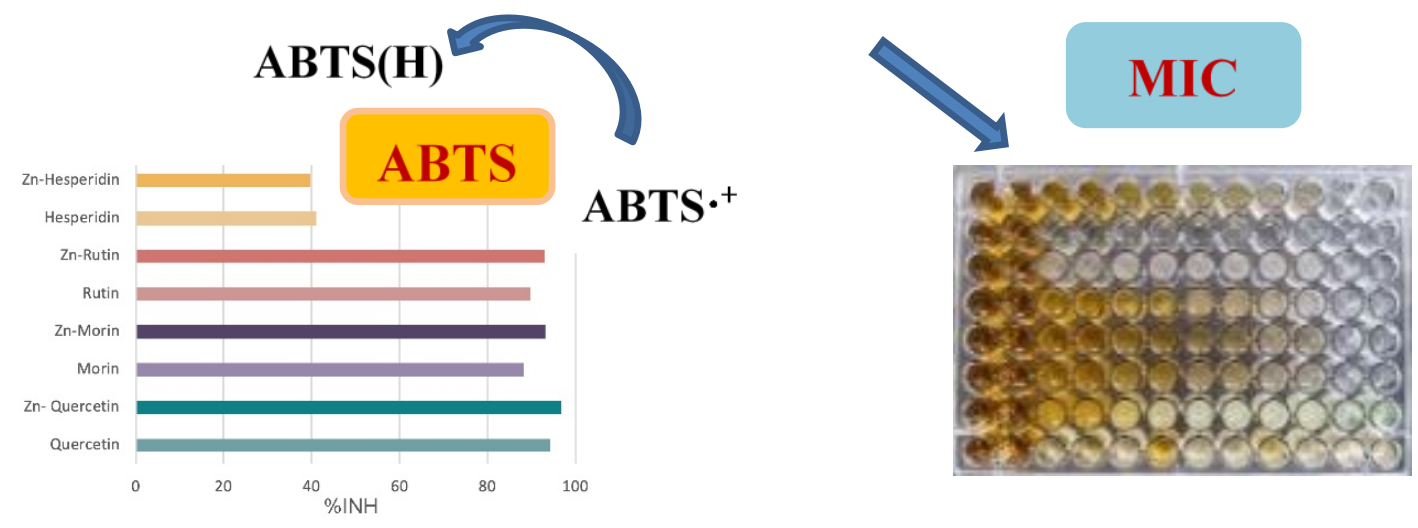

Fig 3. The bioactivity tests applied to flavonoids and their zinc complexes 
For that purpose, several types of tests have been applied. The current study evaluated the antioxidant scavenging activities in the DPPH, FRAP and $\mathrm{ABTS}^{++}$tests. The DPPH assay is a rapid, simple method used to evaluate the antioxidant potential of a compound [38]. DPPH is a stable free radical by virtue of the delocalization of the spare electron over the molecule, and it accepts electrons or hydrogen radicals from donor compounds [39]. The assay is based on the quantitative measurement of the scavenging capacity of antioxidants toward DPPH free radicals by the decrease in their absorbance. This test provides information on the antioxidant's capacity to donate hydrogen atoms or electrons [40]. The FRAP method is based on the principle of reduction of the ferrictripyridyltriazine $\left(\mathrm{Fe}^{3+}-\mathrm{TPTZ}\right)$ complex to ferrous tripyridyltriazine $\left(\mathrm{Fe}^{2+}-\mathrm{TPTZ}\right)$ by the antioxidants in a sample at low $\mathrm{pH}$ [41]. The end product $\left(\mathrm{Fe}^{2+}-\mathrm{TPTZ}\right)$ has a blue color with an absorption maximum at $593 \mathrm{~nm}$, and the change in absorbance is related to the antioxidant capacity of the plasma. The $\mathrm{ABTS}^{-+}$chromophore is produced through the reaction between ABTS and potassium persulfate, which converts ABTS into its radical cation. This radical cation is blue in color and absorbs light at $734 \mathrm{~nm}$. ABTS $^{\cdot+}$ is reactive toward most antioxidants, including phenols, thiols, flavonoids, and vitamin C, etc.

In the case of all three methods, a different profile of antioxidant activity was obtained for the tested flavonoids, although the lowest activity was always shown by hesperidin (Tables 2 and 3 ).

\section{Table 2}

\section{Results of DPPH and FRAP tests}

\begin{tabular}{lccc}
\hline \hline \multirow{2}{*}{ Sample } & DPPH & FRAP & \\
\cline { 2 - 3 } & $\begin{array}{c}\text { Trolox } \\
\left(\mathrm{mg} \mathrm{l}^{-1}\right)\end{array}$ & $\begin{array}{c}\mathrm{C}_{\mathrm{Fe}}^{2+} \\
\left(\mathrm{mmol} \mathrm{l}^{-1}\right)\end{array}$ & Ref. \\
\hline Quercetin & 2.21 & 0.261 & [32] \\
Zn-Quercetin & 2.33 & 0.302 & \\
\hline Morin & 2.36 & 0.260 & [33] \\
Zn-Morin & 2.33 & 0.258 & \\
\hline Rutin & 2.62 & 0.324 & \\
Zn-Rutin & 2.56 & 0.386 & This \\
\hline Hesperidin & 0.47 & 0.137 & article \\
Zn-Hesperidin & 0.55 & 0.122 & \\
\hline \hline
\end{tabular}

In the case of $\mathrm{Zn}$ complexes with quercetin, rutin, and morin, the ABTS and FRAP methods showed them to have similar or higher antioxidant activity compared to the pristine flavonoids, while for DPPH method the increases in activity were obtained for the quercetin and hesperidin $\mathrm{Zn}$ complexes. Interestingly, the solution of $\mathrm{Zn}^{2+}$ itself did not contribute to the antioxidative capacity of the system, according to the results of all three tests.

Table 3

Percentage of ABTS inhibition (\% INH ABTS)

\begin{tabular}{lrrr}
\hline \hline \multirow{2}{*}{ Sample } & \multicolumn{3}{c}{$\%$ INH } \\
\cline { 2 - 4 } & 3 min & 6 min & 20 min \\
\hline Quercetin & 87.89 & 92.47 & 94.32 \\
Zn- Quercetin & 91.78 & 94.24 & 96.77 \\
Morin & 70.96 & 80.25 & 88.18 \\
Zn-Morin & 78.16 & 83.68 & 93.07 \\
Rutin & 71.28 & 74.25 & 89.60 \\
Zn-Rutin & 74.98 & 79.24 & 92.95 \\
Hesperidin & 31.97 & 34.75 & 40.98 \\
Zn-Hesperidin & 36.02 & 37.31 & 39.66 \\
Zn & 2.92 & 2.82 & 2.99 \\
\hline \hline
\end{tabular}

According to the obtained results, the antioxidant activity of the $\mathrm{Zn}$-quercetin complex is slightly higher than that of the flavonoid itself, with the same trend shown in all applied tests. The zinc complexes of the other tested flavonoids did not show the same profile, but varied depending on the specific test. The fact is that the reagents react by different mechanisms and have affinities with different groups of the substrate, so when testing antioxidant activity at least two tests are often performed in parallel.

The influence of the composition of the complex on its antioxidant activity cannot be linked with any certainty. Of these flavonoids, only morin forms a complex with zinc in a composition of 1:1, while other zinc-flavonoid complexes are in the ratio $1: 2$, and thus have more available reactive sites for electron and/or proton transfer to or from reagents. Therefore, it could be assumed that this is one of the reasons for the somewhat lower antioxidant activity, as obtained by the DPPH and FRAP tests, of the Zn-morin complex solution compared to the solution of morin alone. Of course, shedding light on this phenomenon requires further detailed examination, including structural analysis.

In a similar way as for the antioxidative capacity, the antimicrobial effectiveness against standard strains of microorganisms (bacteria/yeasts), of the various flavonoids and their zinc complexes, were tested, and the results are given in the Table 4 as MICs expressed in $\mu \mathrm{g} \mathrm{ml}^{-1}$. 
Table 4

Minimal inhibitory concentrations (MICs) of flavonoids and the respective zinc complexes

\begin{tabular}{|c|c|c|c|c|c|c|c|c|}
\hline \multirow{2}{*}{ Strains } & \multicolumn{8}{|c|}{ "Flavonoids and appropriate zinc complexes $\left(\mu \mathrm{g} \mathrm{ml} \mathrm{l}^{-1}\right)$} \\
\hline & Morin & Zn-Morin & Hesp. & Zn-Hesp. & Rutin & Zn-Rutin & Querc. & Zn-Querc. \\
\hline $\begin{array}{l}\text { S. aureus } \\
\text { (ATCC 6538) }\end{array}$ & 250 & 250 & 500 & 500 & 500 & 500 & 500 & 500 \\
\hline $\begin{array}{l}\text { E. faecalis } \\
\text { (ATCC 29212) }\end{array}$ & 500 & 500 & 500 & 500 & 500 & 500 & 250 & 500 \\
\hline $\begin{array}{l}\text { B. subtilis } \\
\text { (ATCC 6633) }\end{array}$ & 250 & 250 & 500 & 250 & 1000 & 500 & 125 & 125 \\
\hline E. coli (ATCC 8739) & 500 & 500 & 250 & 250 & 500 & 500 & 500 & 250 \\
\hline $\begin{array}{l}\text { K. pneumoniae } \\
\text { (NCIMB 9111) }\end{array}$ & 250 & 500 & 250 & 500 & 500 & 500 & 500 & 500 \\
\hline $\begin{array}{l}\text { S. abony } \\
\text { (NCTC 6017) }\end{array}$ & 500 & 500 & 250 & 500 & 1000 & 1000 & 500 & 500 \\
\hline $\begin{array}{l}\text { P. aeruginosa } \\
\text { (ATCC 9027) }\end{array}$ & 250 & 250 & 250 & 500 & 500 & 500 & 500 & 500 \\
\hline $\begin{array}{l}\text { C. albicans } \\
\text { (ATCC 10231) }\end{array}$ & 250 & 250 & 250 & 250 & 500 & 500 & 500 & 125 \\
\hline Reference & \multicolumn{6}{|c|}{ This article } & \multicolumn{2}{|c|}{ [31] } \\
\hline
\end{tabular}

It can be seen that the tested flavonoids and their zinc complexes possessed slight to moderate antimicrobial potential. For now, the tested systems are not claimed to show anywhere near the effectiveness of antibiotics such as gentamycin, but the results reported herein are especially promising because they illustrate the relative potential of antibacterial activity. If the effects of zinc complexes and the flavonoids themselves are compared, the MIC values are the same against many of the tested strains. Zinc-hesperidin, quercetin and $\mathrm{Zn}$-quercetin exhibited slightly better effectiveness against Bacillus subtilis, but less against the Gram-negative $K$. pneumoniae, Salmonella abony, and Pseudomonas aeruginosa. The $\mathrm{Zn}$-quercetin complex was the most efficient against Candida albicans.

\section{CONCLUSION}

At the time of the Covid-19 pandemic, the consumption of dietary supplements containing zinc has increased due to susceptibility to several viral infections and bacterial co-infections, such as MRSA, S. aureus, etc. that are associated with zinc deficiency in the body, especially in the elderly population [42, 43]. The fact that zinc deficiency is responsible for $16 \%$ of all lower respiratory tract infections in the world indicates the potential benefits of zinc supplementation [44]. The $\mathrm{Zn}-$ quercetin complex can also fight inflammatory agents and protect lung tissue [45]. So, a reasonable question is whether or not a combination of zinc and flavonoids contributes to the resulting efficacy. Because zinc competes with iron and copper, those who take large doses of zinc supplements may develop a deficiency of these minerals. It is best to take them at different times to avoid conflicts around the absorption channels [44]. Flavonoids can inhibit both TMPRSS2 and furin, which cleave the spiked protein SARS-CoV2 , facilitating its infectivity [46]. So, the answer is that the simultaneous use of zinc and flavonoids is reasonable, due to their different mechanisms of action. Also, the possibility of using zincflavonoid complexes is promising, due to their moderate antimicrobial and antioxidant activity.

Acknowledgment. This research was funded by the Ministry of Education, Science and Technological Development, Republic of Serbia through Grant Agreement with University of Belgrade - Faculty of Pharmacy No: 451-03-9/2021-14/200161.

\section{REFERENCES}

[1] R. Miller, S. J. Owens, B. Rørslett, Plants and colour: Flowers and pollination, Optics \& Laser Tech. 43, 282 294 (2011).

DOI: https://doi.org/10.1016/j.optlastec.2008.12.018

[2] K. Ohashi, T. T. Makino, K. Arikawa, Floral colour change in the eyes of pollinators: testing possible constraints and correlated evolution, Funct. Ecol. 29, 1144-1155 (2015). DOI: https://doi.org/10.1111/1365-2435.12420

[3] E. Wollenweber, M. Dörr, M. Christ, Flavonoid aglycones from the leaf and stem exudates of some Geraniaceae species. Natural Product Comm. 6, 15-16 (2011). DOI: https://doi.org/10.1177\%2F1934578X1100600105

[4] A. N. Panche, A. D. Diwan, S. R. Chandra, Flavonoids: an overview J. Nutr. Sci. 5, e47, (2016). DOI: https://doi.org/10.1017/jns.2016.41

[5] C. F. Skibola, M. T. Smith, Potential health impacts of excessive flavonoid intake. Free Radic. Biol. Med. 29, 375-383 (2000).

DOI: https://doi.org/10.1016/S0891-5849(00)00304-X 
[6] S. A. van Acker, D. J. van den Berg, M. N. Tromp, D. H. Griffioen, W. P. van Bennekom, W. J. van der Vijgh, A. Bast, Structural aspects of antioxidant activity of flavonoids, Free Radic. Biol. Med. 20, 331-342 (1996). DOI: https://doi.org/10.1016/0891-5849(95)02047-0

[7] J. Treml, K. Smejkal, Flavonoids as Potent Scavengers of Hydroxyl Radicals, Compr. Rev. Food Sci. 15, 720-738 (2016). DOI: https://doi.org/10.1111/1541-4337.12204

[8] R. K. Gupta, A. K. Patel, N. Shah, A. K. Choudhary, U. K. Jha, U. C. Yadav, P. K. Gupta, U. Pakuwal, Oxidative stress and antioxidants in disease and cancer: A review, Asian Pacific J. Canc. Prev. 15, 4405-4409 (2014). DOI: https://doi.org/10.7314/APJCP.2014.15.11.4405

[9] L. Hooper, P. A. Kroon, E. B. Rimm, J. S. Cohn, I. Harvey, K. A. Le Cornu et al. Flavonoids, flavonoid-rich foods, and cardiovascular risk: a meta-analysis of randomized controlled trials, Am. J. Clin. Nutr. 88, 38 50 (2008). DOI: https://doi.org/10.1093/ajcn/88.1.38

[10] P. Velayutham, A. Babu, D. Liu, Flavonoids and Cardiovascular Health in Complementary and Alternative Therapies and the Aging Population - Chapter 18, Watson RR (Ed), Academic Press, 2009, pp. 371-392.

[11] D. M. Kopustinskiene, V. Jakstas, A. Savickas, J. Bernatoniene, Flavonoids as Anticancer Agents, Nutrients, 12, 457-481 (2020). DOI: https://doi.org/10.3390/nu12020457

[12] I. Gorniak, R. Bartoszewski, J. Kroliczewski, Comprehensive review of antimicrobial activities of plant flavonoids, Phytochem. Rev. 18, 241-272 (2019). DOI: https://doi.org/10.1007/s11101-018-9591-z

[13] S. Lalani, C. L. Poh, Flavonoids as antiviral agents for enterovirus A71 (EV-A71), Viruses, 12, 184-218 (2020). DOI: https://doi.org/10.3390/v12020184

[14] M. Kawai, T. Hirano, S. Higa, J. Arimitsu, M. Maruta, Y. Kuwahara et al., Flavonoids and related compounds as antiallergic substances, Allergol. Int. 56, 113-123 (2007). DOI: https://doi.org/10.2332/allergolint.R-06-135

[15] J. P. Spencer, Flavonoids and brain health: multiple effects underpinned by common mechanisms, Genes. Nutr. 4, 243-250 (2009).

DOI: https://dx.doi.org/10.1007\%2Fs12263-009-0136-3

[16] I. Demonty, Y. Lin, Y. E. Zebregs, M. A. Vermeer, H. C. van der Knaap, M. Jakel et al., The citrus flavonoids hesperidin and naringin do not affect serum cholesterol in moderately hypercholesterolemic men and women, $J$. Nutr. 140, 1615-1620 (2010).

DOI: https://doi.org/10.3945/jn.110.124735

[17] G. Galati, P. J. O'Brien, Potential toxicity of flavonoids and other dietary phenolics: significance for their chemopreventive and anticancer properties. Free Radic. Biol. Med. 37, 287-303 (2004).

DOI: https://doi.org/10.1016/j.freeradbiomed.2004.04.034

[18] M. Stefova, T. Stafilov, S. Kulevanova, HPLC analysis of flavonoid. In: Encyclopedia of Chromatography, $1^{\text {st }}$ ed., J. Cazes (Ed.); Marcel Dekker, Inc., New York, NY, USA, 2003; pp.1-7.

[19] A. M. Engida, N. S. Kasim, Y. A. Tsigie, S. Ismadji, L. H. Huynh, Y-H. Jua, Extraction, identification and quantitative HPLC analysis of flavonoids from sarang semut (Myrmecodia pendan), Industrial Crops and Products, 41, 392-396 (2013). DOI: https://doi.org/10.1016/j.indcrop.2012.04.043
[20] S. W. A. Bligh, O. Ogegbo, Z. T. Wang, Flavonoids by HPLC in Natural Products: Phytochemistry, Botany and Metabolism of Alkaloids, Phenolics and Terpenes. K. Ramawat, J. M. Mérillon (eds), Springer, Berlin, Heidelberg, 2013, pp.2017-2144.

[21] K. Zhang, Y. Zuo, GC-MS Determination of flavonoids and phenolic and benzoic acids in human plasma after consumption of cranberry juice, J. Agric. Food Chem. 52, 222-227 (2004).

DOI: https://doi.org/10.1021/jf035073r

[22] J. H. Lee, Y. Kim, M. H. Hoang et al., Rapid quantification of cellular flavonoid levels using quercetin and a fluorescent diphenylboric acid 2-amino ethyl ester probe, Food Sci. Biotechnol. 23, 75-79, (2014). DOI: https://doi.org/10.1007/s10068-014-0010-y.

[23] D. Barbieri, M. Gabriele, M. Summa, R. Colosimo, D. Leonardi, V. Domenici, L. Pucci, Antioxidant, nutraceutical properties, and fluorescence spectral profiles of bee pollen samples from different botanical origins, Antioxidants, 9, 1001 (2020). DOI: https://dx.doi.org/10.3390\%2Fantiox9101001.

[24] E. S. Gil, R. O. Couto, Flavonoid electrochemistry: a review on the electroanalytical applications, Revista Brasileira de Farmacognosia 23, 542-558 (2020). DOI: https://doi.org/10.1590/S0102-695X2013005000031

[25] J. Hu, Z. Zhang, Application of electrochemical sensors based on carbon nanomaterials for detection of flavonoids. Nanomaterials 10, 2020 (2020). DOI: https://doi.org/10.3390/nano10102020

[26] L. Zhao, W. Liu, S. Xiong, J. Tang, Z. Lou, M. Xie, B. Xia, L. Lin, D. Liao, Determination of total flavonoids contents and antioxidant activity of ginkgo biloba leaf by near-infrared reflectance method, Int. J. Anal. Chem. 2018, 8195784, (2018). DOI: https://dx.doi.org/10.1155\%2F2018\%2F8195784

[27] N. Samad, T. E. Sodunke, A. R. Abubakar et al., The implications of zinc therapy in combating the COVID19 global pandemic, J. Inflamm. Res. 14, 527-550 (2021). DOI: https://doi.org/10.2147/jir.s295377

[28] W. Alker, H. Haase, Zinc and Sepsis. Nutrients 10, 976993 (2018). DOI: https://doi.org/10.3390/nu10080976

[29] N. Roohani, R. Hurrell, R. Kelishadi, R. Schulin, Zinc and its importance for human health: An integrative review. J. Res. Med. Sci. 18, 144-157 (2013).

[30] K. Simmer, R. P. H. Thompson, Zinc in the fetus and newborn, Acts Paediatr. Scand. (Suppl), 319, 158-163 (1985). DOI: https://doi.org/10.1111/j.1651-2227.1985.tb10126.x

[31] B. D. Chiranjib, K. P. S. Kumar, A potential medicinal importance of zinc in human health and chronic disease, Int. J. Pharm. Biomed. Sci. 1, 5-11 (2010).

[32] S. Uskoković-Marković, M. Milenković, L. Pavun, Zinc-quercetin complex - from determination to bioactivity, Acta Agricult. Serb. 25, 113-120 (2020), DOI: http://dx.doi.org/10.5937/AASer2050113U

[33] L. Pavun, A. Janošević Ležaić, S. Uskoković-Marković, Spectrophotometric determination of morin in strawberries and their antioxidant activity, Arh. Farm. 71, 1-17 (2021). DOI: http://dx.doi.org/10.5937/arhfarm71-30503

[34] C. F. Hsu, H. Peng, C. Basle, J. Travas-Sejdic, P. A. Kilmartin. $\mathrm{ABTS}^{\cdot+}$ scavenging activity of polypyrrole, 
polyaniline and poly(3,4-ethylenedioxythiophene), Polym. Int. 60, 69-77 (2011).

DOI: https://doi.org/10.1002/pi.2912

[35] Y. Wei, M. Guo, Zinc-binding sites on selected flavonoids, Biol. Trace Elem. Res. 161, 223-230 (2014). DOI: https://doi.org/10.1007/s12011-014-0099-0

[36] L. Pavun, M. Jelikić-Stankov, P. Đurđević, A. Ćirić, S. Uskoković-Marković, Zinc Complex-Based Determination of Rutin in Dietary Supplements, Maced. J. Chem. Chem. Eng. 35, 13-18 (2016). DOI: http://dx.doi.org/10.20450/mjcce.2016.897

[37] L. Pavun, S. Uskoković-Marković, Spectrophotometric determination of hesperidin in supplements and orange juices, Hrana i ishrana, 60, 18-23 (2019). DOI: http://dx.doi.org/10.5937/HraIsh1901018P

[38] S. B. Kedare, R. P. Singh, Genesis and development of DPPH method of antioxidant assay, J. Food Sci. Technol. 48, 412-422 (2011). DOI: https://doi.org/10.1007/s13197-011-0251-1

[39] K. Sridhar, A. L. Charles, In vitro antioxidant activity of Kyoho grape extracts in DPPH and ABTS assays: Estimation methods for EC50 using advanced statistical programs, Food Chem. 275, 41-49 (2019). DOI: https://doi.org/10.1016/j.foodchem.2018.09.040

[40] K. Sirivibulkovit, S. Nouanthavong, Y. Sameenoi, Paper-based DPPH assay for antioxidant activity analysis, Anal. Sci. 34, 795-800 (2018). DOI: https://doi.org/10.2116/analsci.18p014
[41] I. F. Benzie, J. J. Strain, The ferric reducing ability of plasma (FRAP) as a measure of "antioxidant power": the FRAP assay, Anal. Biochem. 239, 70-76 (1996). DOI: https://doi.org/10.1006/abio.1996.0292

[42] R. Derwand, M. Scholz, Does zinc supplementation enhance the clinical efficacy of chloroquine/ hydroxychloroquine to win today's battle against COVID-19? Med. Hypotheses 142, 109815 (2020). DOI: https://doi.org/10.1016/j.mehy.2020.109815

[43] A. V. Skalny, L. Rink, O. P. Ajsuvakova, et al. Zinc and respiratory tract infections: perspectives for COVID-19 (Review), Int. J. Mol. Med.46, 17-26 (2020). DOI: https://doi.org/10.3892/ijmm.2020.4575

[44] I. Wessels, B. Rolles, L. Rink, The Potential Impact of Zinc Supplementation on COVID-19 Pathogenesis, Front. Immunol. 11, 1712-1723 (2020). DOI: https://doi.org/10.3389/fimmu.2020.01712

[45] M. S. Refat, R. Z. Hamza, A. M. A. Adam, H. A. Saad, A. A. Gobouri, F. S. Al-Harbi, et al. Quercetin/Zinc complex and stem cells: A new drug therapy to ameliorate glycometabolic control and pulmonary dysfunction in diabetes mellitus: Structural characterization and genetic studies, PLOS ONE, 16, e0246265. (2021). DOI: https://doi.org/10.1371/journal.pone.0246265

[46] M. Russo, S. Moccia, C. Spagnuolo, I. Tedesco, G. L. Russo, Roles of flavonoids against coronavirus infection, Chem. Biol. Interact. 328, 109211, (2020). DOI: https://doi.org/10.1016/j.cbi.2020.109211 